\title{
The role of RAGE in the diabetic neuropathy
}

\author{
Rola białka RAGE w neuropatii cukrzycowej
}

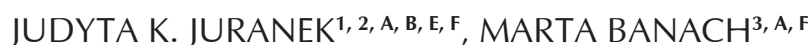

${ }^{1}$ Diabetes Research Program, New York University Langone Medical Center, New York, USA

${ }^{2}$ Department of Pathophysiology, Faculty of Medical Sciences, University of Warmia and Mazury in Olsztyn

${ }^{3}$ Department of Neurology, Jagiellonian University Medical College in Cracow

A - Study Design, B - Data Collection, C - Statistical Analysis, D - Data Interpretation, E - Manuscript Preparation, F - Literature Search, $\mathbf{G}$ - Funds Collection

Summary Neuropathy is one of the most common complications of diabetes, affecting from $50 \%$ to $60 \%$ of all long-term diabetic patients. In Europe every year hundreds of thousands of new diabetic neuropathy cases are diagnosed, imparing patients' health and well-being and generating additional financial costs for patients and health care providers. So far, despite intensive studies, efforts have failed to establish a coherent image of the pathogenesis of this disease. It is believed that several factors contribute to the onset of neuropathy such as: lack of or poor glycemic control, impaired perineural circulation, oxidative stress, increased protein glycation associated combined with increased production of advanced glycation end products (AGEs, advanced glycation end-products) and enhanced activity of RAGE (receptor for advanced glycation end-products). RAGE plays an important role in a number of pathological processes such as: inflammation, oxidative stress and metabolic disturbances and has been reported to contribute to the progression of numerous disorders such as diabetes, atherosclerosis, nephropathy, various tumors and last but not least neurodegenerative diseases. The ongoing preclinical and clinical studies on the role of RAGE in the development of diabetic neuropathy aimed at providing a more detailed image of RAGE contribution to neurodegeneration, will likely lead to the development of new therapies, supplementing current diabetic neuropathy treatment schemes with RAGE modulating agents benefiting patients' health and reducing overall costs of the treatment.

Key words: diabetic neuropathy, neurodegeneration, RAGE.

Streszczenie Neuropatia jest jednym z najczęściej diagnozowanych powikłań cukrzycy, dotykających od 50 do $60 \%$ wszystkich chorych z długotrwałą cukrzycą. W Europie corocznie przybywa kilkaset tysięcy nowych przypadków osób dotkniętych neuropatią cukrzycową, przyczyniając się do pogorszenia ogólnego stanu ich zdrowia i samopoczucia oraz generując dodatkowe koszty zarówno dla chorych. jak i dla zakładów opieki zdrowotnej. Do tej pory, mimo intensywnych wysiłków badawczych, nie udało się ustalić spójnego obrazu patomechanizmu tej choroby; uważa się, iż do wystąpienie neuropatii przyczynia się kilka czynników, takich jak: brak kontroli lub zła kontrola glikemiczna, upośledzenie krążenia okołonerwowego, stres oksydacyjny oraz wzmożona glikacja i związana z tym obecność w krwi szkodliwych końcowych produktów zaawansowanej glikacji (advanced glycation end-products, AGE) oraz zwiększona aktywność białka RAGE (receptor for advanced glycation end-products; receptor końcowych produktów zaawansowanej glikacji). RAGE odgrywa ważną rolę w procesach zapalnych, stresie oksydacyjnym oraz różnorodnych zaburzeniach komórkowych towarzyszącym wielu procesom chorobowym. Rola RAGE została udokumentowana w patomechanizmie wielu schorzeń, m.in. cukrzycy, zaburzeniach sercowo-naczyniowych, niewydolności nerek, chorobach nowotworowych oraz procesach neurodegeneracyjnych. Prowadzone obecnie badania przedkliniczne i kliniczne dotyczące roli RAGE w rozwoju neuropatii dążą do nakreślenia pełniejszego obrazu udziału RAGE w neurodegeneracji, by w przyszłości umożliwić rozszerzenie obecnych sposobów leczenia o dodatkowe środki terapeutyczne modulujące działanie RAGE, przyczyniając się do poprawy stanu chorych cierpiących na tą uciążliwą przypadłość, jaką stanowi neuropatia cukrzycowa.

Słowa kluczowe: neuropatia cukrzycowa, neurodegeneracja, RAGE.

Fam Med Prim Care Rev 2015; 17(4): 316-318

\section{Background}

Neuropathy is one of the most common complications of diabetes, affecting from $50 \%$ to $60 \%$ of all long-term diabetic patients. In Europe every year hundreds of thousands of new diabetic neuropathy cases are diagnosed, impairing patients' health and well-being and generating additional financial costs for patients and health care providers [1].

The most common symptoms of diabetic neuropathy reported by patients are: numbness, tingling, neuropathic pain and muscle weakness of the upper and lower extremities; the latter often contributing to the increased risk of burns, injuries and ulcers, leading in extreme cases, to gangrene and limb amputation [2].
So far, despite intensive studies, efforts have failed to establish a coherent image of the pathogenesis of this disease. It is believed that several factors contribute to the onset of the disease such as: lack of or poor glycemic control, impaired perineural circulation, oxidative stress, increased protein glycation associated combined with increased production of advanced glycation end-products (AGEs, advanced glycation end-products) and enhanced activity of RAGE (receptor for advanced glycation end-products) [3].

\section{Many faces of RAGE}

RAGE belongs to the immunoglobulin superfamily and plays an important role in a number of pathological pro- 


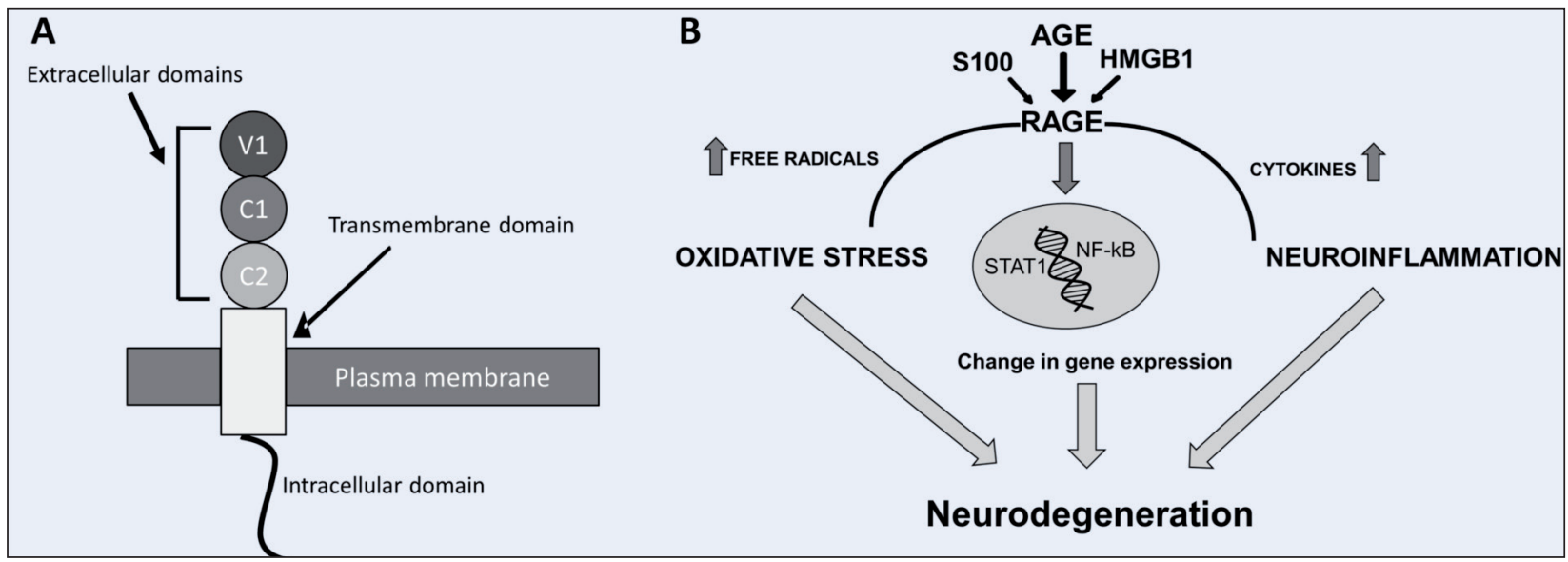

Figure 1. RAGE chemical structure and mechanism of action

A) multiligand RAGE is a transmembrane receptor with three extracellular domains - V1, C1, and C2, participating in interaction with numerous ligands e.g. AGEs, S100 protein family or HMGB1. Transmembrane domain serves as an anchor, securing RAGE to the cell membrane. Intracellular cytoplasmic domain enables interactions with cytoplasmic proteins such as mDia1 - a member of formin family, regulating functions of cytoskeletal proteins, such as actin or neurofilament;

B) a simplified mechanism of RAGE action in cells of the nervous system. RAGE-ligand interaction induce a cascade of metabolic changes, causing changes in the expression of key cell proteins and contributing to the release of free radicals and inflammatory cytokines. The accumulation of harmful substances on the outside and inside a cell causes functional changes leading in the long run to cell damage and apoptosis.

cesses such as: inflammation, oxidative stress and metabolic disturbances. It has been reported to contribute to the progression of numerous disorders such as diabetes, atherosclerosis, nephropathy, various tumors and last but not least neurodegenerative diseases $[4,5]$. In the latter case, over the last decade RAGE has gained a lot of attention as an important factor contributing to the onset or progression of several neurodegenerative diseases, among others: Parkinson's, Huntington's, Alzheimer's, Amyotrophic Lateral Sclerosis diabetic neuropathy, familial amyloid polyneuropathy, Charcot Marie disease [6-15].

Although the detailed mechanism of RAGE role in diabetic neuropathy remains unclear, studies indicate that the harmful effects of RAGE are triggered by its binding to inflammatory ligands, such as AGEs, S100 or HMGB1 exacerbating inflammation and oxidative stress and triggering activation of nuclear transcription factors such as NF-kB or STAT1 affecting the function of numerous key cell proteins [16-18].

\section{Soluble RAGE - a low molecular weight RAGE inhibitor}

Soluble RAGE acts as RAGE decoy, inhibiting its function and lowering levels of RAGE-ligands, effectively preventing RAGE-ligand negative effects on cells $[19,20]$. Preclinical studies in animal models demonstrated that sRAGE administration is beneficial in several conditions such as diabetes related atherosclerosis, polycystic kidney disease and autoimmune myocarditis, alleviating symptoms and improving overall outcome of the disease. Furthermore, recent studies revealed that soluble RAGE might be a useful tool in predicting the progression and/or risk and severity of several disorders such as: amyotrophic lateral sclerosis, chronic obstructive pulmonary disease, acute coronary syndrome, ul- cerative colitis, familial combined hyperlipidemia, diabetic nephritis and others [21-28].

\section{Experimental and clinical studies on RAGE and diabetic neuropathy}

Tests on genetically modified mouse models of diabetic neuropathy showed that genetic RAGE knockout slows down the neurodegenerative processes subsequent to diabetic nerve damage, reducing neuroinflammation and accelerating neuronal regeneration [14]. Furthermore, immunohistochemical analysis of peripheral nerves obtained from patients with symptoms of diabetic neuropathy showed the increased presence of RAGE and its ligands (S100, CML and HMGB1) supporting the role of this protein in the pathogenesis of diabetic neuropathy $[29,30]$. In vivo studies conducted in diabetic patients focused on finding the correlation between patient's sage, skin biopsy RAGE expression and the severity of diabetic neuropathy have shown that there is a statistically significant correlation between the increase in the concentration of RAGE, patient's age and severity of the disease, further emphasizing the role of RAGE in the pathogenesis of the disease [31].

\section{Conclusions}

The ongoing preclinical and clinical studies on the role of RAGE in the development of diabetic neuropathy aimed at providing a more detailed image of RAGE contribution to neurodegeneration, will likely lead to the development of new therapies, supplementing current diabetic neuropathy treatment schemes with RAGE modulating agents benefiting patients health and reducing overall costs of the treatment. 


\section{References}

1. Tesfaye S, Selvarajah D. Advances in the epidemiology, pathogenesis and management of diabetic peripheral neuropathy. Diab Metab Res Rev 2012; 28(Suppl. 1): 8-14.

2. Tesfaye S, Kempler P. Painful diabetic neuropathy. Diabetologia 2005; 48(5): 805-807.

3. Manigrasso MB, Juranek J, Ramasamy R, et al. Unlocking the biology of RAGE in diabetic microvascular complications. Trends in endocrinology and metabolism: TEM 2014; 25(1): 15-22.

4. Bierhaus A, Humpert PM, Morcos M, et al. Understanding RAGE, the receptor for advanced glycation end products. J Mol Med (Berl) 2005; 83(11): 876-886.

5. Schmidt AM, Stern DM. Receptor for age (RAGE) is a gene within the major histocompatibility class III region: implications for host response mechanisms in homeostasis and chronic disease. Frontiers in Bioscience: a journal and virtual library 2001; 6: D1151-D1160.

6. Sasaki N, Takeuchi M, Chowei H, et al. Advanced glycation end products (AGE) and their receptor (RAGE) in the brain of patients with Creutzfeldt-Jakob disease with prion plaques. Neurosci Lett 2002; 326(2): 117-120.

7. Teismann P, Sathe K, Bierhaus A, et al. Receptor for advanced glycation end products (RAGE) deficiency protects against MPTP toxicity. Neurobiol Aging 2012; 33(10): 2478-2490.

8. Fang F, Lue LF, Yan S, et al. RAGE-dependent signaling in microglia contributes to neuroinflammation, abeta accumulation, and impaired learning/memory in a mouse model of Alzheimer's disease. FASEB 2010; 24(4): 1043-1055.

9. Anzilotti S, Giampa C, Laurenti D, et al. Immunohistochemical localization of receptor for advanced glycation end (RAGE) products in the R6/2 mouse model of Huntington's disease. Brain Res Bull 2012; 87(2-3): 350-358.

10. Sousa MM, Du Yan S, Fernandes R, et al. Familial amyloid polyneuropathy: receptor for advanced glycation end products-dependent triggering of neuronal inflammatory and apoptotic pathways. J Neurosci 2001; 21(19): 7576-786.

11. Bierhaus A, Haslbeck KM, Humpert PM, et al. Loss of pain perception in diabetes is dependent on a receptor of the immunoglobulin superfamily. JCI 2004; 114(12): 1741-1751.

12. Haslbeck KM, Bierhaus A, Erwin S, et al. Receptor for advanced glycation endproduct (RAGE) - mediated nuclear factor-kappaB activation in vasculitic neuropathy. Muscle Nerve 2004; 29(6): 853-860.

13. Witzke KA, Vinik Al, Grant LM, et al. Loss of RAGE defense: a cause of Charcot neuroarthropathy? Diab Care 2011; 34(7): $1617-1621$.

14. Juranek JK, Geddis MS, Song F, et al. RAGE deficiency improves postinjury sciatic nerve regeneration in type 1 diabetic mice. Diabetes 2013; 62(3): 931-943.

15. Cardoso I, Brito M, Saraiva MJ. Extracellular matrix markers for disease progression and follow-up of therapies in familial amyloid polyneuropathy V30M TTR-related. Dis Markers 2008; 25(1): 37-47.

16. Casula M, lyer AM, Spliet WG, et al. Toll-like receptor signaling in amyotrophic lateral sclerosis spinal cord tissue. Neuroscience 2011; 179: 233-243.

17. Abu El-Asrar AM, Nawaz MI, Siddiquei MM, et al. High-mobility group box-1 induces decreased brain-derived neurotrophic factor-mediated neuroprotection in the diabetic retina. Mediat Inflamm 2013; 2013:863036.

18. Pietkiewicz J, Seweryn E, Bartys A, et al. Receptors for advanced glycation end products and their physiological and clinical significance. Post Hig Med Dosw (Online) 2008; 62: 511-523.

19. Schmidt AM, Hori O, Chen JX, et al. Advanced glycation endproducts interacting with their endothelial receptor induce expression of vascular cell adhesion molecule-1 (VCAM-1) in cultured human endothelial cells and in mice. A potential mechanism for the accelerated vasculopathy of diabetes. JCI 1995; 96(3): 1395.

20. Schmidt AM, Yan SD, Wautier JL, et al. Activation of receptor for advanced glycation end products: a mechanism for chronic vascular dysfunction in diabetic vasculopathy and atherosclerosis. Circ Res 1999; 84(5): 489-497.

21. Lee EJ, et al, Soluble receptor for advanced glycation end products inhibits disease progression in autosomal dominant polycystic kidney disease by down-regulating cell proliferation. FASEB J 2015; 29(8): 3506-3514.

22. Jandeleit-Dahm KA, Lassila M, Allen TJ. Advanced glycation end products in diabetes-associated atherosclerosis and renal disease: interventional studies. Ann N Y Acad Sci 2005; 1043: 759-766.

23. Yang WI, et al. Blocking the receptor for advanced glycation end product activation attenuates autoimmune myocarditis. Circ J 2014; 78(5): 1197-1205.

24. Iwamoto $\mathrm{H}$, et al. Soluble receptor for advanced glycation end-products and progression of airway disease. BMC Pulm Med 2014; 14: 68.

25. Santilli F, et al. Decreased plasma endogenous soluble RAGE, and enhanced adipokine secretion, oxidative stress and platelet/ /coagulative activation identify non-alcoholic fatty liver disease among patients with familial combined hyperlipidemia and/or metabolic syndrome. Vascul Pharmacol 2015; 72: 16-24.

26. Jensen LJ, Flyvbjerg A, Bjerre M. Soluble receptor for advanced glycation end product: a biomarker for acute coronary syndrome. Biomed Res Int 2015; 2015: 815-942.

27. Wang J, et al. Genetic polymorphisms of RAGE and risk of ulcerative colitis in a Chinese population. Immunol Lett 2015 (Epub ahead of print).

28. Ilzecka J. Serum-soluble receptor for advanced glycation end product levels in patients with amyotrophic lateral sclerosis. Acta Neurol Scand 2009; 120(2): 119-122.

29. Juranek JK, Aleshin A, Rattigan EM, et al. Morphological changes and immunohistochemical expression of RAGE and its ligands in the sciatic nerve of hyperglycemic pig (Sus Scrofa). Biochem Insights 2010; 3: 47-59.

30. Juranek JK, Kothary P, Mehra A, et al. Increased expression of the receptor for advanced glycation end-products in human peripheral neuropathies. Brain Behav 2013; 3(6): 701-709.

31. Bekircan-Kurt CE, Uceyler N, Sommer C. Cutaneous activation of rage in nonsystemic vasculitic and diabetic neuropathy. Muscle Nerve 2014; 50: 377-383.

Address for correspondence:

Dr n. wet. Judyta K. Juranek

Diabetes Research Program

New York University Langone Medical Center

550 First Avenue, Smilow 906, New York, NY, 10016, USA

Tel.: +1 646726 1705, +48 507 013-659

E-mail: judytajuranek@gmail.com 